
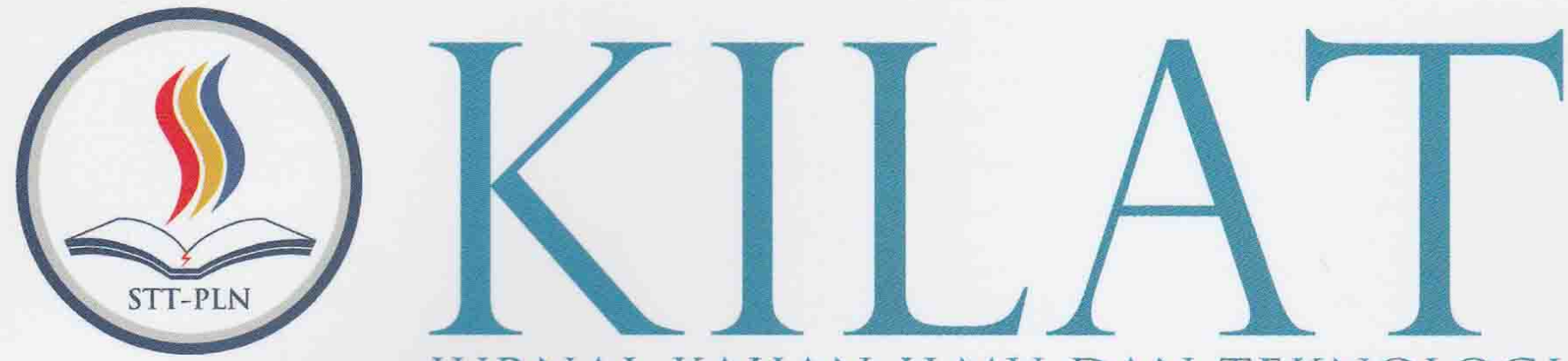

JURNAL KAJIAN ILMU DAN TEKNOLOGI

Endah Lestari: Irma Wirantina K: Ranti Hidayawanti

Faisal:

Muhammad Ridwan: Mardawati

Gita Puspa Artiani: Indah Handayasari

Kresna Ramanda; Irmawati Carolina

Ratna Mutu Manikam:

Farid Setiawan

Rayung Wulan

Roni Kartika Pramuyanti

Rr. Mekar Ageng Kinasti; Djoko Nugroho Notodisuryo

Satria;

Ayu Setiawati Agustini

Syam Gunawan: Pritasari Palupiningsih

Ali Ridho Gumelar: Anton: Ummu Radiyah

M. Yoga Distra Sudirman: Yessy Fitriani
ANALISA TAMAN ATAP DALAM UPAYA MENGURANGI LIMPASAN AIR HUJAN PADA BANGUNAN PERKOTAAN

OPTIMASI DIAGRAM LAYANAN PEMBELIAN DALAM MENDUKUNG MANAJEMEN HUBUNGAN PELANGGAN

OPTIMALISASI PENGOLAHAN SAMPAH ORGANIK DENGAN TEKNOLOGI BIODIGESTER SEBAGAI UPAYA KONSERVASI LINGKUNGAN

SELEKSI FITUR ALGORITMA NEURAL NETWORK MENGGUNAKAN PARTICLE SWARM OPTIMIZATION UNTUK MEMPREDIKSI KELAHIRAN PREMATUR

RANCANG BANGUN MEDIA BELAJAR FISIKA DASAR UNTUK MAHASISWA BERBASIS ANDROID

ANALISIS GLOBAL POSITIONING INFRASTRUKTUR DAN JARINGAN SOSIAL MEDIA DALAM BISNIS APLIKASI TRANSPORTASI DARAT ONLINE DI JAKARTA

PENGARUH INOVASI ANTENA PADA SIARAN TELEVISI MOBIL

PEMANFAATAN LIMBAH PEMBAKARAN BATUBARA (BOTTOM ASH) PADA PLTU SURALAYA SEBAGAI MEDIA TANAM DALAM UPAYA MENGURANGI PENCEMARAN LINGKUNGAN

PENERAPAN METODE GRAPHIC RATING SCALE (GRS) DALAM PENILAIAN KINERJA KARYAWAN

PEMBENTUKAN MODEL KLASIFIKASI DATA LAMA STUDI MAHASISWA STMIK INDONESIA MENGGUNAKAN DECISION TREE DENGAN ALGORITMA NBTREE

IMPLEMENTASI LOAD BALANCING DENGAN ALGORITMA EQUAL COST MULTI PATH (ECMP)

RANCANGAN SISTEM PENILAIAN HASIL KINERJA MULTI COMPANY DAN CROSS BUSINESS SECTOR 


\title{
SELEKSI FITUR ALGORITMA NEURAL NETWORK MENGGUNAKAN PARTICLE SWARM OPTIMIZATION UNTUK MEMPREDIKSI KELAHIRAN PREMATUR
}

\author{
${ }^{1}$ Kresna Ramanda; ${ }^{2}$ Irmawati Carolina \\ 1) STMIK Nusa Mandiri Jakarta \\ Jl. Damai No. 8, Warung Jati Barat, Jakarta Selatan \\ kresna.kra@nusamandiri.ac.id \\ 2) AMIK BSI Jakarta \\ JI. R.S Fatmawati No 24 ,Pondok Labu, Jakarta Selatan \\ irmawati.imc@bsi.ac.id
}

\begin{abstract}
ABSTRAK
Persalinan prematur, didefinisikan sebagai persalinan pada wanita hamil dengan usia gestasi 20 - 36 minggu. Penelitian yang berhubungan dengan kelahiran prematur sudah pernah dilakukan oleh peneliti yaitu dengan menggunakan metode neural network. Namun penelitian tersebut hanya manyajikan tentang hasil sensitivitas dan spesifisitas. Hasil Penelitian yang menggunakan metode neural network dalam memprediksi kelahiran prematur mempunyai nilai akurasi yang dihasilkan masih kurang akurat dan hanya sebatas menyajikan tentang hasil sensitivitas dan spesifisitas. Dalam penelitian ini dibuatkan model algoritma neural network dan model algoritma neural network berbasis particle swarm optimization untuk mendapatkan arsitektur dalam memprediksi kelahiran prematur dan memberikan nilai akurasi yang lebih akurat pada data set RSUPN Cipto Mangunkusumo, RS Sumber Waras dan secara keseluruhan. Setelah dilakukan pengujian dengan dua model yaitu algoritma neural network dan algoritma neural network berbasis particle swarm optimization maka hasil yang didapat adalah algoritma neural network menghasilkan nilai akurasi sebesar 94,60\% , 96,40\%, 91,33\% dan nilai AUC sebesar 0,973,0,982, 0,953 namun setelah dilakukan penambahan yaitu algoritma neural network berbasis particle swarm optimization nilai akurasi sebesar 95,20 $\%, 96,80 \%, 92,40 \%$ dan nilai AUC sebesar 0,979, 0,987, 0,965. Sehingga kedua metode tersebut memiliki perbedaan tingkar akurasi yaitu sebesar 0,60 \%,0,40\%, 1,07\% dan perbedaan nilai AUC sebesar 0,006 , $0,005,0,012$.
\end{abstract}

Kata kunci: Kelahiran prematur, Neural network, Particle Swarm Optimization

\section{ABSTRACT}

Premature birth, defined as delivery in pregnant women with gestation age 20 - 36 weeks. Research related to preterm birth has been done by the researchers by using the neural network method. However such research only showcase about the results of the sensitivity and specificity. The results of research using the method of neural network in predicting preterm birth has a value of the resulting accuracy is still less accurate and only limited to presenting the results of the sensitivity and specificity. In this study produced a model of the neural network algorithm and model of neural network algorithm based on particle swarm optimization to get the architecture in predicting preterm birth and gives a more accurate value for accuracy on a data set of RSUPN Cipto Mangunkusumo, RS Sumber Waras and in its entirety. After you are done testing with two models of neural network algorithms and neural network algorithm based on particle swarm optimization and the results obtained are the neural network algorithm generates value accuracy of $94,60 \%, 96,40 \%, 91,33 \%$, and AUC values of 0,973, 0,982, 0,953, however, after the addition of the neural network algorithm based on particle swarm optimization value accuracy of $95,20 \%, 96,80 \%, 92,40 \%$ and AUC values of 0,979,0,987, 0,965 . So both of these methods has the distinction of accuracy which amounted to $0.60 \%, 0.40 \%, 1.07 \%$ and AUC value difference of $0.006,0.005,0.012$.

Keywords : Premature birth, Neural network, Particle Swarm Optimization.

\section{PENDAHULUAN}

Persalinan preterm menurut Health Technology Assessment Indonesia (2009), didefinisikan sebagai persalinan pada wanita hamil dengan usia gestasi 20 - 36 minggu. Health Technology Assessment Indonesia (2009), melakukan pengkajian terhadap prediksi persalinan preterm, Dengan hasil menunjukkan persalinan preterm perlu diprediksi dan ditatalaksana untuk mengurangi morbiditas dan mortalitas neonatal akibat kelahiran preterm. Penelitian tentang prediksi kelahiran prematur telah dilakukan dengan melalui algoritma Neural Network. Dari hasil penelitian akhir yang diuji menggunakan algoritma Neural Network oleh Catley et al(2006), menunjukkan bahwa algoritma Neural Network efektif dalam menciptakan model umum.Secara khusus, sensitivitas meningkat menjadi 35,6 \% untuk memprediksi kelahiran prematur dengan spesifisitas $88,6 \%$, dan menurun sedikit menjadi $37,3 \%$ untuk memprediksi risiko tinggi kelahiran prematur dengan spesifisitas 92,2 \%.Menurut Park,Lee \& Choi (2009), Particle swarm optimization (PSO) merupakan algoritma optimasi yang efektif yang dapat memecahkan masalah yang 
ada pada algoritma neural network yang pada umumnya menggunakan algoritma backpropagation .Menurut Ling,Nguyen \& Chan (2009), Particle swarm optimization memiliki perbandingan lebih untuk pemilihan fitur dan memiliki kinerja lebih unggul untuk banyak masalah optimasi dengan lebih cepat dan tingkat konvergensi yang lebih stabil .Penelitian ini dibatasi pada peningkatan algoritma neural network dan optimasi bobot atribut dengan particle swarm optimization dengan cara menganalisis sejumlah atribut yang menjadi bobot atribut (attribute weight) untuk prediksi pasien berpotensi melahirkan prematur.

\section{METODE PENELITIAN}

Menurut Dawson (2009),Metode penelitian yang umum digunakan ada empat yaitu Action Reserch Experiment, Case Study, dan Survey. Penelitian adalah mencari melalui proses yang metodis untuk menambahkan pengetahuan itu sendiri dan dengan yang lainnya, oleh penemuan fakta dan wawasan tidak biasa. Pengertian lainnya, penelitian adalah sebuah kegiatan yang bertujuan untuk membuat kontribusi orisinal terhadap ilmu pengetahuan.

Menurut Berndtssom et al (2008), Dalam konteks sebuah penelitian, pendekatan metode yang digunakan untuk memecahkan masalah, diantaranya: mengumpulkan data, merumuskan hipotesis atau proposisi, menguji hipotesis, hasil penafsiran, dan kesimpulan yang dapat dievaluasi secara independen oleh orang lain. Sedangkan menurut Dawson (2009), terdapat empat metode penelitian yang umum digunakan, diantaranya: Action Research, Experiment, Case Study, dan Survey.

Penelitian ini menggunakan penelitian eksperimen. Penelitian eksperimen melibatkan penyelidikan perlakuan pada parameter atau variabel tergantung dari penelitinya dan menggunakan tes yang dikendalikan oleh si peneliti itu sendiri, dengan metode penelitian sebagai berikut:

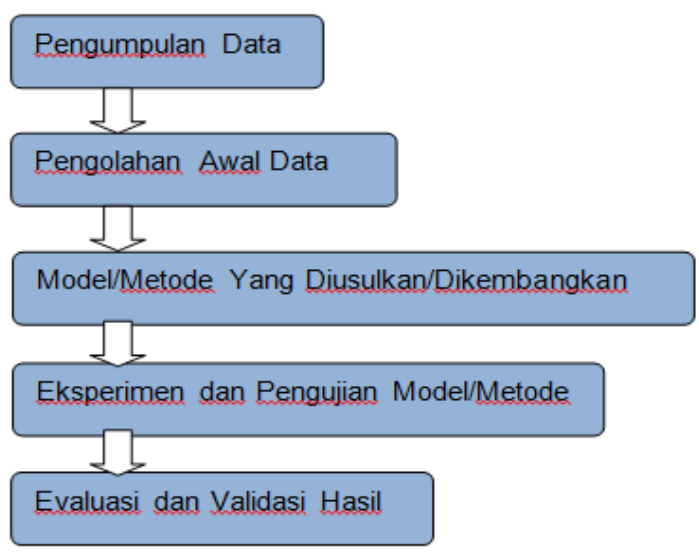

Sumber : Dawson ( 2009)

Gambar 2.1 Tahapan Penelitian

\subsection{Pengumpulan Data}

Data yang didapat dari RSUPN Cipto Mangunkusumo Jakarta adalah data pasien gynekologi dengan jumlah data sebanyak 500 record, serta Data pasien gynekologi pada RS Sumber Waras Jakarta dengan jumlah data sebanyak 250 record sehingga jumlah data yang digunakan sebanyak 750 record. terdri dari 11 variabel atau atribut. Variabel tersebut ada yang tergolong variable predictor atau pemrediksi yaitu variable yang dijadikan sebagai penentu kelahiran prematur, dan variabel tujuan yaitu variabel yang dijadikan sebagai hasil kelahiran. Adapun variabel predictor yaitu usia, sistol, diastol, riwayat darah tinggi, riwayat keguguran, riwayat prematur, stress (trauma), konsumsi rokok, kehamilan ganda,keputihan.

\subsection{Pengolahan Awal Data}

Menurut Vercelis (2009),Untuk mendapatkan data yang berkualitas, beberapa teknik yang dilakukan sebagai berikut:

a. Data validation, untuk mengidentifikasikan dan menghapus data yang ganjil (outlier/noise), data yang tidak konsisten, dan data yang tidak lengkap (missing value). Data pasien yang ada akan di identifikasi apakah ada data yang ganjil (outlier/noise), data yang tidak konsisten, dan data yang tidak lengkap (missing value).

b. Data integration and transformationi, untuk meningkatkan akurasi dan efisiensi algoritma. Data yang digunakan dalam penulisan ini bernilai kategorikal. Data ditransformasikan kedalam software Rapidminer.

c. Data size reduction and discritization, untuk memperoleh data set dengan jumlah atribut dan record yang lebih sedikit tetapi bersifat informatif. Pada tahap ini data untuk algoritma neural network digunakan data kategorikal yang telah ditransformasikan kedalam bentuk angka.

Tabel 2.1 Tabel Atribut yang digunakan

\begin{tabular}{|c|l|l|}
\hline No & \multicolumn{1}{|c|}{ Atribut } & \multicolumn{1}{c|}{ Nilai } \\
\hline 1 & Usia & $\begin{array}{l}\text { 0= Tidak Rawan } \\
\text { 1= Rawan }\end{array}$ \\
\hline 2 & Sistol & $\begin{array}{l}\text { 0= Rendah } \\
\text { 1= Normal } \\
\text { 2= Tinggi }\end{array}$ \\
\hline 3 & Diastol & $\begin{array}{l}\text { 0= Rendah } \\
\text { 1= Normal } \\
\text { 2= Tinggi }\end{array}$ \\
\hline 4 & Riwayat Darah Tinggi & 0= Tidak; $1=$ Ya \\
\hline 5 & Riwayat Keguguran & 0= Tidak; $1=$ Ya \\
\hline 6 & Riwayat Prematur & 0= Tidak; $1=$ Ya \\
\hline 7 & Stress Trauma & 0= Tidak; $1=$ Ya \\
\hline 8 & Konsumsi Rokok & 0= Tidak; $1=$ Ya \\
\hline 9 & Kehamilan Ganda & 0= Tidak; $1=$ Ya \\
\hline 10 & Keputihan & 0= Tidak; $1=$ Ya \\
\hline 11 & Hasil & $\begin{array}{l}\text { Prematur ; } \\
\text { Tidak_prematur }\end{array}$ \\
\hline
\end{tabular}




\subsection{Model Yang Diusulkan}

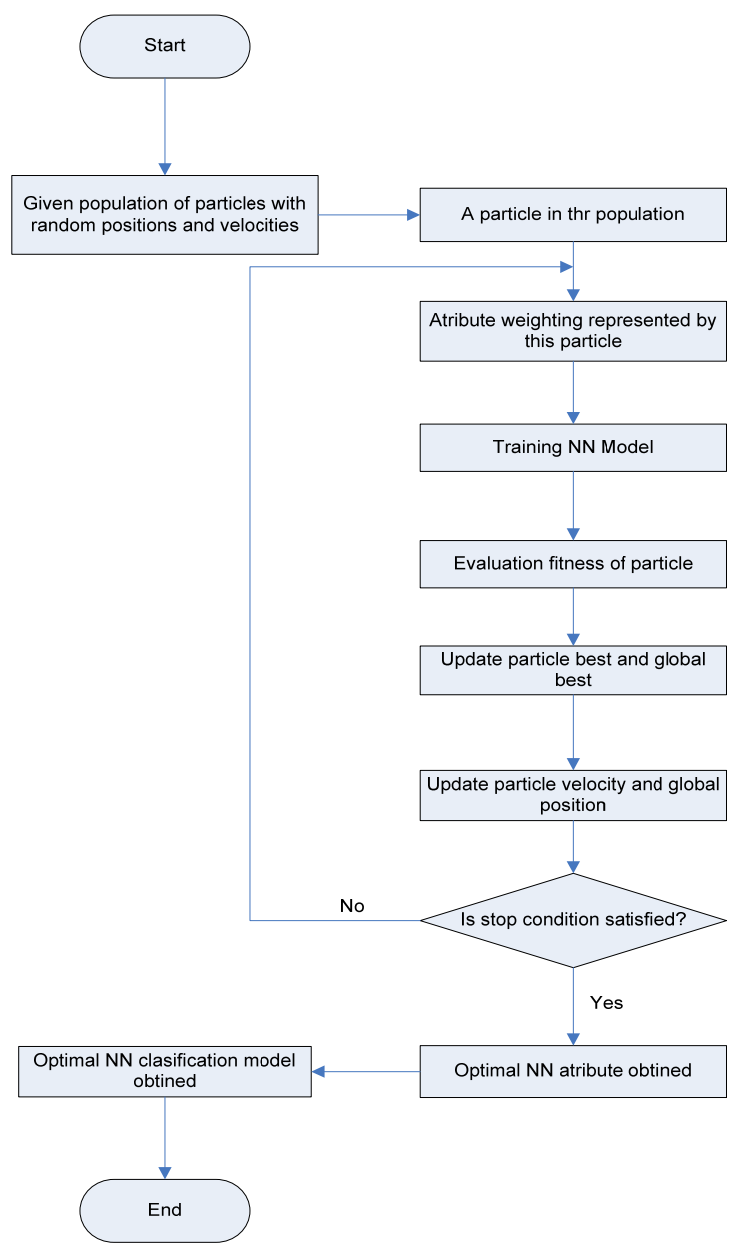

Gambar 2.2 Model yang diusulkan

\subsection{Eksperimen dan Pengujian Metode}

Pada penelitian kali ini yang digunakan adalah penelitian Experiment. Penelitian eksperimen melibatkan penyelidikan hubungan kausal menggunakan tes dikendalikan oleh si peneliti itu sendiri. Dalam penelitian eksperimen digunakan spesifikasi software dan hardware sebagai alat bantu dalam penelitian pada Tabel 3.2:

Tabel 2.2 Spesifikasi Hardware dan Software

\begin{tabular}{|l|l|}
\hline \multicolumn{1}{|c|}{ Software } & \multicolumn{1}{c|}{ HardWare } \\
\hline $\begin{array}{l}\text { Sistem Operasi Windows } \\
\mathrm{Xp}\end{array}$ & Intel Pentium dual Core \\
\hline $\begin{array}{l}\text { Data Mining : RapidMiner } \\
5.3\end{array}$ & Memory : $2 \mathrm{~GB}$ \\
\hline & Harddisk :250 GB \\
\hline
\end{tabular}

Untuk memilih arsitektur neural network yang tepat, agar menghasilkan nilai akurasi dan nilai AUC yang terbesar, diperlukan pengaturan (adjustment) untuk parameter-parameter neural network. Berikut ini adalah parameter parameter yang membutuhkan adjustment:

a. Training cycle, learning rate, dan momentum

b. Hidden Layer

c. Arsitektur neural network

\subsection{Evaluasi dan Validasi Hasil}

Model yang diusulkan pada penelitian tentang prediksi kelahiran prematur adalah dengan menerapkan neural network dan neural network berbasis Particle swarm optimization. Penerapan algoritma neural network dengan menentukan nilai training cycle terlebih dahulu. Setelah didapatkan nilai akurasi dan AUC terbesar, nilai training cycle tersebut akan dijadikan nilai yang akan digunakan untuk mencari nilai akurasi dan AUC tertinggi pada learning rate dan momentum. Setelah ditemukan nilai yang paling tinggi dari training cycle, learning rate dan momentum selanjutnya adalah menentukan ukuran (size) pada hidden layer tersebut. Sedangkan penerapan algoritma neural network berbasis Particle swarm optimization berdasarkan pada nilai training cycle pada algoritma tersebut. Setelah ditemukan nilai akurasi yang paling ideal dari parameter tersebut langkah selanjutnya adalah menentukan nilai learning rate dan momentum. Setelah ditemukan nilai akurasi yang paling ideal dari parameter tersebut langkah selanjutnya adalah menentukan hidden layer dan neuron size sehingga terbentuk struktur algoritma yang ideal untuk pemecahan masalah tersebut.

\section{HASIL DAN PEMBAHASAN}

\section{A. Metode Neural Network}

Penelitian ini melakukan uji coba pada nilai training cycles ditentukan dengan cara memasukkan nilai range dari 100 sampai dengan 1500 untuk training cycles, serta nilai 0.1 sampai dengan nilai 0.9 untuk learning rate dan nilai 0.0 sampai dengan 0.9 untuk momentum,serta dengan percobaan penentuan nilai neuron size terhadap 1 hidden layer dengan menggunakan data training.

Tabel 3.1 Pemberian nilai terbaik terhadap training model algoritma neural network

\begin{tabular}{|c|c|c|c|}
\hline \multirow[b]{2}{*}{ Nilai } & \multirow{2}{*}{$\begin{array}{c}\text { Data Set } \\
\text { RSUPN Cipto } \\
\text { Mangunkusumo }\end{array}$} & \multirow[b]{2}{*}{$\begin{array}{c}\text { RS } \\
\text { Sumber } \\
\text { Waras }\end{array}$} & \multirow[b]{2}{*}{$\begin{array}{l}\text { Keselu- } \\
\text { ruhan }\end{array}$} \\
\hline & & & \\
\hline $\begin{array}{c}\text { Hidden } \\
\text { Layer Size }\end{array}$ & 7 & 1 & 7 \\
\hline $\begin{array}{l}\text { Training } \\
\text { Cycles }\end{array}$ & 300 & 100 & 200 \\
\hline $\begin{array}{l}\text { Learning } \\
\text { Rate }\end{array}$ & 0,1 & 0,2 & 0,2 \\
\hline Momentum & 0,5 & 0,9 & 0,2 \\
\hline Accuracy & 94,60 & 96,40 & 91,33 \\
\hline Auc & 0,973 & 0,982 & 0,953 \\
\hline
\end{tabular}

Berdasarkan data penelitian diatas maka dapat terlihat bahwa dengan satu hidden layer dengan neuron size 7, mendapatkan nilai accuracy sebesar $94.60 \%$ dan nilai AUC sebesar 0.973 untuk data set RSUPN Cipto Mangunkusumo, dengan satu hidden layer dengan neuron size 1 , mendapatkan nilai accuracy sebesar $96.40 \%$ dan nilai AUC sebesar 0.982 untuk data set RS Sumber Waras, serta dengan satu hidden layer dengan neuron size 7, mendapatkan nilai accuracy sebesar 91.33\% dan nilai AUC sebesar 0.953 untuk data set keseluruhan. 
Dari eksperimen terbaik diatas maka didapatkan arsitektur neural network seperti pada gambar berikut.

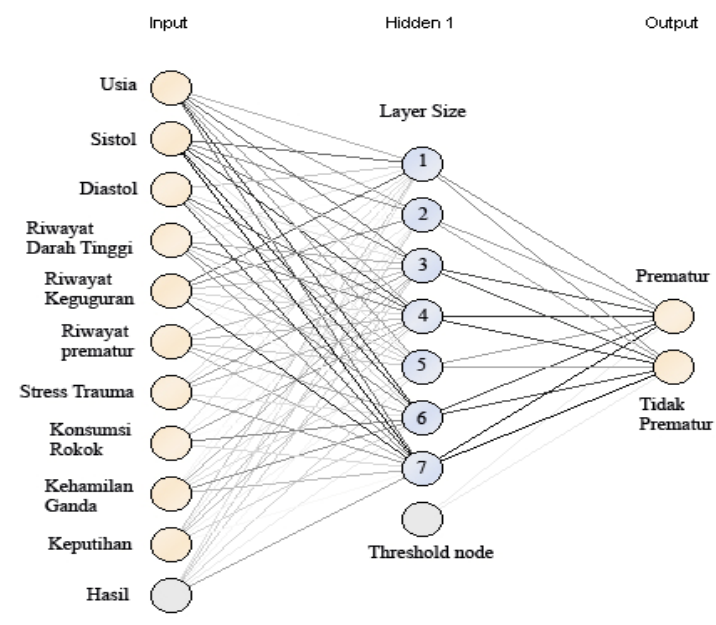

Gambar 3.1. Arsitektur Neural Network Yang Terbentuk pada data set RSUPN Cipto Mangunkusumo

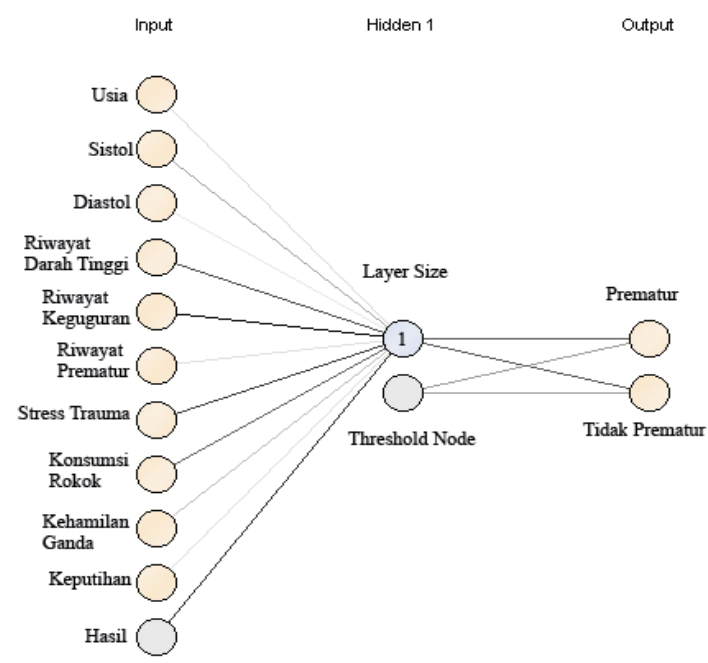

Gambar 3.2. Arsitektur Neural Network Yang Terbentuk pada data set RS Sumber Waras

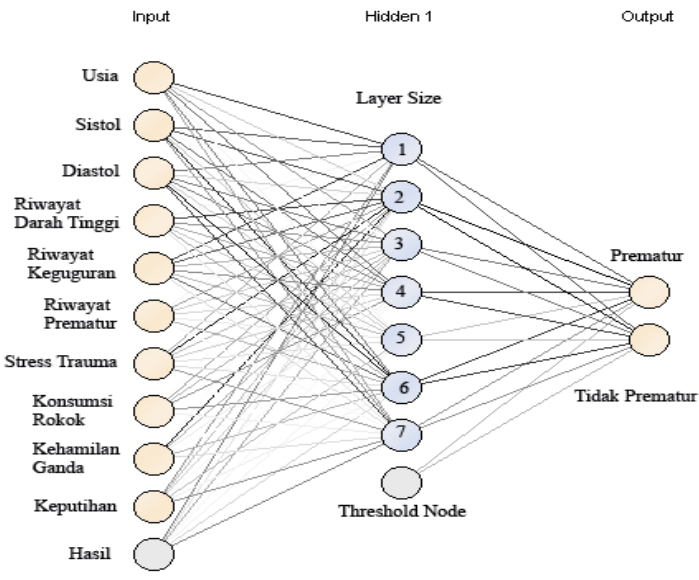

Gambar 3.3. Arsitektur Neural Network Yang Terbentuk pada data set keseluruhan
3.1 Metode Neural Network Berbasis Particle Swarn Optimization.

Pada penelitian prediksi kelahiran prematur menggunakan algoritma neural network berbasis Particle Swarm Optimization. Particle Swarm Optimization memiliki pencarian kinerja yang lebih baik untuk memecahkan banyak masalah optimasi dengan lebih cepat dan tingkat konvergensi yang stabil.

Berdasarkan hasil dari uji coba dengan menggunakan algoritma neural network maka data training tersebut akan diseleksi dengan attribute yang digunakan yaitu usia , sistol, diastol, riwayat darah tinggi, riwayat keguguran ,riwayat prematur,trauma,konsumsi rokok,kehamilan ganda,keputihan dan 1 atribut sebagai label yaitu hasil.

Tabel 3.2 Bobot Atribut dengan Metode Neural Network berbasis PSO

\begin{tabular}{|c|c|c|c|}
\hline \multirow[b]{2}{*}{ Atribute } & \multicolumn{3}{|c|}{ DATA SET } \\
\hline & $\begin{array}{c}\text { RSUPN } \\
\text { Cipto } \\
\text { Mangun- } \\
\text { kusumo }\end{array}$ & $\begin{array}{c}\text { RS } \\
\text { Sumber } \\
\text { Waras }\end{array}$ & $\begin{array}{c}\text { Keselu- } \\
\text { ruhan }\end{array}$ \\
\hline Usia & 0,407 & 0,756 & 0,368 \\
\hline Sistol & 0,196 & 0,674 & 0,768 \\
\hline Diastol & 1 & 0 & 0,83 \\
\hline $\begin{array}{l}\text { Riwayat } \\
\text { Darah Tinggi }\end{array}$ & 0,538 & 0,087 & 1 \\
\hline $\begin{array}{l}\text { Riwayat } \\
\text { Keguguran }\end{array}$ & 0,283 & 0,237 & 0,887 \\
\hline $\begin{array}{l}\text { Riwayat } \\
\text { Prematur }\end{array}$ & 0,464 & 0 & 0,662 \\
\hline Trauma & 1 & 0,154 & 0,115 \\
\hline $\begin{array}{l}\text { Konsumsi } \\
\text { Rokok }\end{array}$ & 1 & 0,991 & 1 \\
\hline $\begin{array}{l}\text { Kehamilan } \\
\text { Ganda }\end{array}$ & 0 & 0,536 & 0,292 \\
\hline Keputihan & 0 & 0,781 & 0 \\
\hline
\end{tabular}

Dari hasil uji coba menggunakan algoritma neural network berbasis particle swarm optimization diperoleh beberapa atribut-atribut yang berpengaruh terhadap bobot atribut untuk data set RSUPN Cipto Mangunkusumo yaitu: usia , sistol , diastol,riwayat darah tinggi,riwayat keguguran, riwayat prematur,trauma,konsumsi rokok. Berdasarkan hasil uji coba kehamilan ganda dan keputihan tidak berpengaruh terhadap bobot attribute. untuk data set RS Sumber Waras yaitu: usia ,sistol ,riwayat darah tinggi,riwayat keguguran,trauma,konsumsi rokok,kehamilan ganda,keputihan. Berdasarkan hasil uji coba diastole dan riwayat prematur tidak berpengaruh terhadap bobot attribute.sedangkan untuk data set keseluruhan yaitu: usia,sistol, diastol, riwayat darah tinggi,riwayat keguguran ,riwayat prematur,trauma,konsumsi rokok,kehamilan ganda. Berdasarkan hasil uji coba keputihan tidak berpengaruh terhadap bobot attribute.

Berdasarkan hasil model algortima neural network berbasis particle swarm optimization dapat dilakukan uji coba pada nilai training cycles ditentukan dengan cara memasukkan nilai range dari 100 sampai dengan 1500 untuk training cycles, 
serta nilai 0.1 sampai dengan nilai 0.9 untuk learning rate dan nilai 0.0 sampai dengan 0.9 untuk momentum, serta dengan percobaan penentuan nilai neuron size terhadap 1 hidden layer dengan menggunakan data training.

Tabel 3.3 Pemberian nilai terbaik terhadap training model algoritma neural network berbasis PSO

\begin{tabular}{|l|c|c|c|}
\hline \multirow{2}{*}{ Nilai } & \multicolumn{3}{|c|}{ DATA SET } \\
\cline { 2 - 4 } & $\begin{array}{c}\text { RSUPN } \\
\text { Cipto } \\
\text { Mangun- } \\
\text { kusumo }\end{array}$ & $\begin{array}{c}\text { RS } \\
\text { Sumber } \\
\text { Waras }\end{array}$ & Keseluruhan \\
\hline $\begin{array}{l}\text { Hidden } \\
\text { Layer Size }\end{array}$ & 6 & 7 & 11 \\
\hline $\begin{array}{l}\text { Training } \\
\text { Cycles }\end{array}$ & 100 & 300 & 600 \\
\hline $\begin{array}{l}\text { Learning } \\
\text { Rate }\end{array}$ & 0.4 & 0.3 & 0.2 \\
\hline Momentum & 0.7 & 0.2 & 0.3 \\
\hline Accuracy & $95,20 \%$ & $96,80 \%$ & $92,40 \%$ \\
\hline Auc & 0,979 & 0,987 & 0,965 \\
\hline
\end{tabular}

Hasil terbaik pada percobaan diatas adalah dengan satu hidden layer dengan size 6 dengan accuracy yang dihasilkan sebesar $95,20 \%$ dan AUC-nya 0.979 untuk data set RSUPN Cipto Mangunkusumo, dengan satu hidden layer dengan size 7 dengan accuracy yang dihasilkan sebesar 96,80\% dan AUC-nya 0.987 untuk data set RS Sumber Waras, sedangkan dengan satu hidden layer dengan size 11 dengan accuracy yang dihasilkan sebesar 92,40\% dan AUC-nya 0.965 untuk data set keseluruhan.

\subsection{Hasil Pengujian Metode}

\section{a. Confusion Matrix}

Berdasarkan data training yang diolah sebanyak 500 record pada data set RSUPN Cipto Mangunkusumo dan 250 data di RS Sumber Waras diperoleh hasil sebagai berikut:

Tabel 3.4 Nilai accuracy, sensitivity, specificity, ppv dan npv metode neural network

\begin{tabular}{|l|c|c|c|}
\hline \multirow{2}{*}{ NILAI } & \multicolumn{3}{|c|}{ DATA SET } \\
\cline { 2 - 4 } & $\begin{array}{c}\text { RSUPN Cipto } \\
\text { Mangun- } \\
\text { kusumo }\end{array}$ & $\begin{array}{c}\text { RS } \\
\text { Sumber } \\
\text { Waras }\end{array}$ & $\begin{array}{c}\text { Keselu- } \\
\text { ruhan }\end{array}$ \\
\hline Accuracy & 94,60 & 96,40 & 91,33 \\
\hline Sensitivity & 97,38 & 98,84 & 92,54 \\
\hline Specificity & 91,42 & 95,12 & 90,21 \\
\hline PPV & 92,86 & 91,40 & 89,81 \\
\hline Npv & 96,82 & 99,36 & 92,84 \\
\hline
\end{tabular}

Tabel 3.5 Nilai accuracy, sensitivity, specificity, ppv dan $n p v$ metode neural network berbasis PSO

\begin{tabular}{|c|c|c|c|}
\hline \multirow{2}{*}{ NILAI } & \multicolumn{3}{|c|}{ DATA SET } \\
\cline { 2 - 4 } & $\begin{array}{c}\text { RSUPN } \\
\text { Cipto } \\
\text { Mangun- } \\
\text { kusumo }\end{array}$ & $\begin{array}{c}\text { RS } \\
\text { Sumber } \\
\text { Waras }\end{array}$ & $\begin{array}{c}\text { Keselu- } \\
\text { ruhan }\end{array}$ \\
\hline Accuracy & 95,20 & 96,80 & 92,40 \\
\hline Sensitivity & 96,72 & 100,00 & 91,58 \\
\hline Specificity & 93,36 & 95,15 & 93,24 \\
\hline PPV & 94,64 & 91,40 & 93,30 \\
\hline Npv & 95,91 & 100,00 & 91,51 \\
\hline
\end{tabular}

b. Evaluasi ROC Curve

Berikut adalah gambar grafik perbandingan antara neural network dan neural network berbasis PSO.

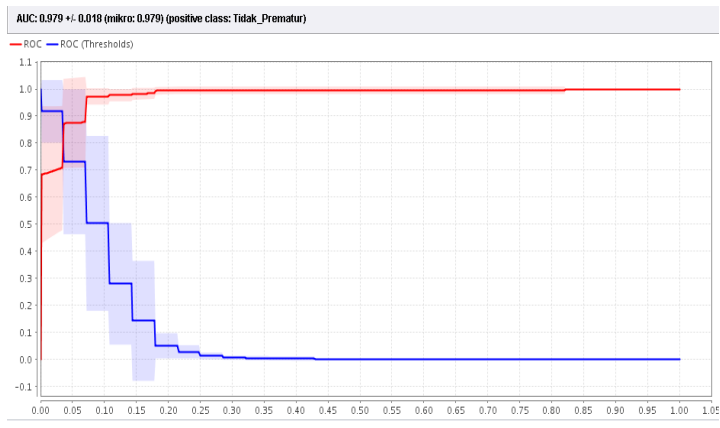

Gambar 3.4. ROC Curve dengan metode neural network

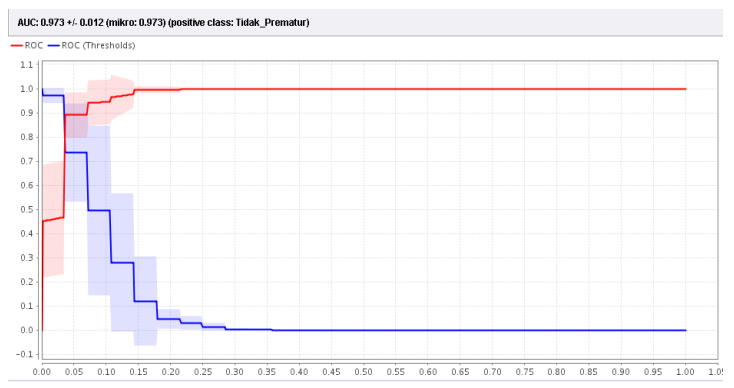

Gambar 3.5. ROC Curve dengan metode neural network berbasis PSO

Untuk evaluasi menggunakan ROC curve sehingga menghasilkan nilai AUC untuk model algortima Neural network menghasilkan nilai 0,973 dengan diagnosa Excellent classification, sedangkan untuk algortima neural netwok berbasi PSO menghasilkan nilai 0,979 dengan nilai diagnosa Excellent classification, dan selisih keduanya sebesar 0,006 untuk data set RSUPN Cipto Mangunkusumo. nilai AUC untuk model algortima Neural network menghasilkan nilai 0,982 dengan diagnosa Excellent classification, sedangkan untuk algortima neural netwok berbasi PSO menghasilkan nilai 0,987 dengan nilai diagnosa Excellent classification, dan selisih keduanya sebesar 0,005 untuk data set RS Sumber Waras. nilai AUC untuk model algortima Neural network menghasilkan nilai 0,953 dengan diagnosa 
Excellent classification, sedangkan untuk algortima neural netwok berbasi PSO menghasilkan nilai 0,965 dengan nilai diagnosa Excellent classification, dan selisih keduanya sebesar 0,012 untuk data set secara keseluruhan. Dengan demikian algortima Neural Network berbasis PSO dapat memberikan solusi untuk permasalahan dalam prediksi hasil kelahiran prematur.

\section{KESIMPULAN}

1. Dari penelitian yang dilakukan, penentuan nilai parameter yang telah dioptimasi menggunakan particle swarm optimization terbukti mampu meningkatkan akurasi prediksi pada kelahiran prematur.

2. Dapat disimpulkan bahwa algoritma neural network berbasis particle swarm optimization lebih akurat dalam memprediksi kelahiran prematur.

3. Model yang terbentuk nantinya akan dikembangkan atau diimpelementasikan kedalam sebuah aplikasi, sehingga dapat membantu dan memudahkan bagi para praktisi kesehatan dalam mendiagnosa kelahiran prematur.

Walaupun model algoritma neural network yang digunakan sudah memberikan hasil yang lebih baik, namun ada beberapa hal yang dapat ditambahkan untuk penelitian selanjutnya, adapun saran-saran yang diusulkan:

a. Adanya penelitian lebih lanjut dengan dataset yang lebih banyak dan lebih baik.

b. Penelitian dapat dipergunakan untuk pihak rumah sakit sebagai bahan pertimbangan untuk memprediksi kelahiran prematur sehingga dapat meningkatkan akurasi dalam prediksi kelahiran prematur.

c. Adanya penambahan atribut lain seperti berat badan dan hasil dari pemeriksaan USG dan pemeriksaan laboratorium lainnya.

d. Dapat digunakan pada studi kasus lain, tidak hanya dalam bidang kesehatan tetapi juga pada bidang-bidang lainnya.

e. Penelitian ini dapat dikembangkan dengan metode optimasi lain seperti Ant Colony Optimization (ACO), Genetic Algorithm (GA) dan lain-lain. Dan penelitian ini dapat juga dikembangkan dengan menggunakan metode klasifikasi lain seperti Support Vector Machine, K-Nearest Neighbours, naïve bayes dan lain-lain

\section{DAFTAR PUSTAKA}

[1]. Health Technology Assessment Indonesia,.(2009). Prediksi Persalinan Preterm. Dirjen Bina Pelayanan Medik Kemenetrian Kesehatan Republik Indonesia.

[2]. Catley,C.,Frize,M.,Walker,R.,Petriu,C.(2006). Predicting High-Risk Preterm Birth Using Artificial Neural Networks. IEEE TRANSACTIONS ON INFORMATION TECHNOLOGY IN BIOMEDICINE, VOL. 10, NO. 3, JULY 2006.540-549.
[3]. Park, T. S., Lee, J. H., \& Choi, B. (2009). Optimization for Artificial Neural Network with Adaptive inertial weight of particle swarm optimization. Cognitive Informatics, IEEE International Conference , 481-485.

[4]. Ling, S. H., Nguyen, H. T., \& Chan, K. Y. (2009). A New Particle Swarm Optimization Algorithm for Neural Network Optimization. Network and System Security, third International Conference , 516-521.

[5]. Santosa, B,. (2007). Data mining teknik pemanfaatan data untuk keperluan bisnis. Yogyakarta: Graha ilmu

[6]. Witten, I. H., Frank, E., \& Hall, M. A. (2011).Data Mining: Practical Machine Learning and Tools. Burlington: Morgan Kaufmann Publisher.

[7]. Astuti, E. D. (2009). Pengantar Jaringan Saraf Tiruan. Wonosobo: Star Publishing.

[8]. Shukla, A., Tiwari, R., \& Kala, R. (2010). Real Life Application of Soft Computing. CRC Press.

[9]. Salappa, A., Doumpos, M., \& Zopounidis, C. (2007). Feature Selection Algorithms in Classification Problems: An Experimental Evaluation. Systems Analysis, Optimization and Data Mining in Biomedicine , 199-212.

[10]. Han, J., \& Kamber, M. (2007). Data Mining Concepts and Technique. Morgan Kaufmann publisher.

[11]. Dawson, C. W. (2009). Projects in Computing and Information System A Student's Guide. England: Addison-Wesley.

[12]. Berndtssom, M., Hansson, J., Olsson, B., \& Lundell, B. (2008). A Guide for Students in Computer Science and Information Systems. London: Springer.

[13]. Vercellis, C. (2009). Business Intelligence : Data Mining and Optimization for Decision Making. John Wiley \& Sons, Ltd 